\title{
Need for the Implementation of Antibiotic Policy in India: An Overview
}

\section{IJCRR \\ Section: Healthcare \\ ISI Impact Factor \\ (2019-20): 1.628 \\ IC Value (2019): 90.81 \\ $\operatorname{SJIF}(2020)=7.893$}

(c) (i) (3)

Copyright@IJCRR

\section{Rihana Begum Patnool ${ }^{1}$, Ashish Wadhwani' ${ }^{2}$ Balasubramaniam V³, Sivasankaran Ponnusankar ${ }^{1}$}

\author{
'Department of Pharmacy Practice, JSS College of Pharmacy,]SS Academy of Higher Education and Research, Ooty - 643 001, Tamilnadu, \\ India; 'Department of Pharmaceutical Biotechnology, JSS College of Pharmacy, JSS Academy of Higher Education and Research, Ooty-643001, \\ Tamilnadu, India; 3Associate Professor, Department of Surgery, Govt. Medical College \& Hospital, Ooty- 643 001, Tamilnadu, India.
}

\section{ABSTRACT}

World health organization accepted that antimicrobial resistance is a natural phenomenon, there is an urgent need for comprehensive national plans, based on a multi-sectorial approach and with sustainable financing to fight antimicrobial resistance globally. AMR continues to pose a significant public health problem in terms of mortality and economic loss. Studies related to antimicrobial drugs usage, determining factors and development of antimicrobial drug resistance, provincial discrepancy and interventional strategies is a big challenge for any developing country. This review article aims to highlight the importance of Antibiotic policy and its implementation in every health care system to make physicians, general practitioners, and other stakeholders aware of the issue of AMR and its factors and what can be done. Scoping review was done using ScienceDirect, Web of Science, EconLit, and PubMed. To discuss some of the challenges in the implementation of policies in India such as varied discernments about antibiotic use and AMR among key stakeholders, inappropriate antibiotic use and to achieve the aim of this review was performed by collecting around 80 published articles from 1999 to 2020 . Initial suitable antibiotic treatment has been shown to reduce mortality, the span of stay in ICU and hospital. Early correct antibiotic choosen have also served to the reduction in antimicrobial costs. The hospitals which are having antibiotic policy shown decreased morbidity and mortality due to antibioticresistant infections. In developing countries, antimicrobial stewardship programs are emerging up, which will help to develop antibiotic policies for management of infections in various settings. This article focuses on the current status and implementation of antibiotic policy in Indian healthcare settings like the primary, secondary and tertiary hospital to combat antimicrobial resistance.

Key Words: Antimicrobial resistance, Antibiotic policy, Antibiotics, Antimicrobial Stewardship Program, Developing Country, Indian Healthcare

\section{INTRODUCTION}

Antimicrobial resistance is a unique community health problem especially in developing countries where comparatively easy availability and higher consumption of medicines have led to the disproportionately higher prevalence of inappropriate use of antibiotics and greater levels of resistance compared to developed countries ${ }^{1-3}$ Supervision of frequent and lethal bacterial infections has been significantly compromised by the appearance and quick increase of antibiotic-resistant bacteria. The Global Antibiotic Resistance Partnership (GARP) was started to begin the practice of developing actionable policy recommendations relevant to low- and middle-income countries. ${ }^{4,5}$ Auta et al., ${ }^{6}$ recently demonstrated that obtaining antibiotics without restrictions is possible in many countries through prescriptions at com- munity pharmacies. In their meta-analysis on the effects of the unregulated sale of antibiotics conducted during 20002017, the authors represented data suggesting that the largely pooled proportion of antibiotics sold with no a prescription had reached $72 \%$. Proportions are high even in partially developed countries such as Mexico, where a ban on the sale of antibiotics without a prescription was instituted only nine years ago. ${ }^{7}$ Every time an antibiotic is used - whether appropriately or not, in human beings or animals- the probability of the development and spread of antibiotic-resistant bacteria is increased. ${ }^{8,9}$ In the evolution of drug resistance in bacteria 'Drug selection pressure' becomes the single most important factor. The reasons for selection of drug are multifactorial and involve both human and animal use. While antibiotic resistance is first and foremost a medical problem, the factors that control the spread of resistance are epidemiological,

\section{Corresponding Author:}

Dr. Sivasankaran Ponnusankar, Department of Pharmacy Practice, JSS College of Pharmacy, JSS Academy of Higher Education and Research, Ooty - 643 001, Tamilnadu; Email: ponnusankarsivas@gmail.com

ISSN: 2231-2196 (Print) ISSN: 0975-5241 (Online)

Received: $13.08 .2020 \quad$ Revised: 16.10 .2020

Accepted: 01.12 .2020

Published: 03.03 .2021 
social, cultural, ecological and economic. Physicians, veterinarians, patients, retailers and healthcare facilities - from huge pharmacies to limited drug sellers - have little enthusiasm (economic or otherwise) to recognize the consequences of their use of antibiotics on others, especially on future generations. ${ }^{5}$ The microbial infection burden in India is among the highest in the world. ${ }^{10}$ Accordingly, antibiotics will perform a perilous role in limiting morbidity and mortality in the nation. As an indicator of disease burden, pneumonia causes an estimated 410,000 deaths in India each year. ${ }^{11}$ It is the number-one destroyer of children health. ${ }^{12}$ Many of these leads to deaths which occur as patients do not have access to life-saving antibiotics when and where these are needed. At the other extreme, antimicrobial drugs are used in circumstances where these drugs cannot be expected to recover the patient's condition, mainly as a treatment for the frequent cold and unsophisticated cases of diarrhoea (which are appropriately treated with oral rehydration therapy). ${ }^{5}$ The crude infectious disease mortality rate in India today is 5169.5 per 100,000 persons (according to Global Burden of Disease (GBD) study, carried out by Institute for Health Metrics and Evaluation, the USA from 1990 to 2017) and is twice the rate prevailing in the United States when antibiotics were introduced (roughly 200 per 100,000 persons). ${ }^{13}$

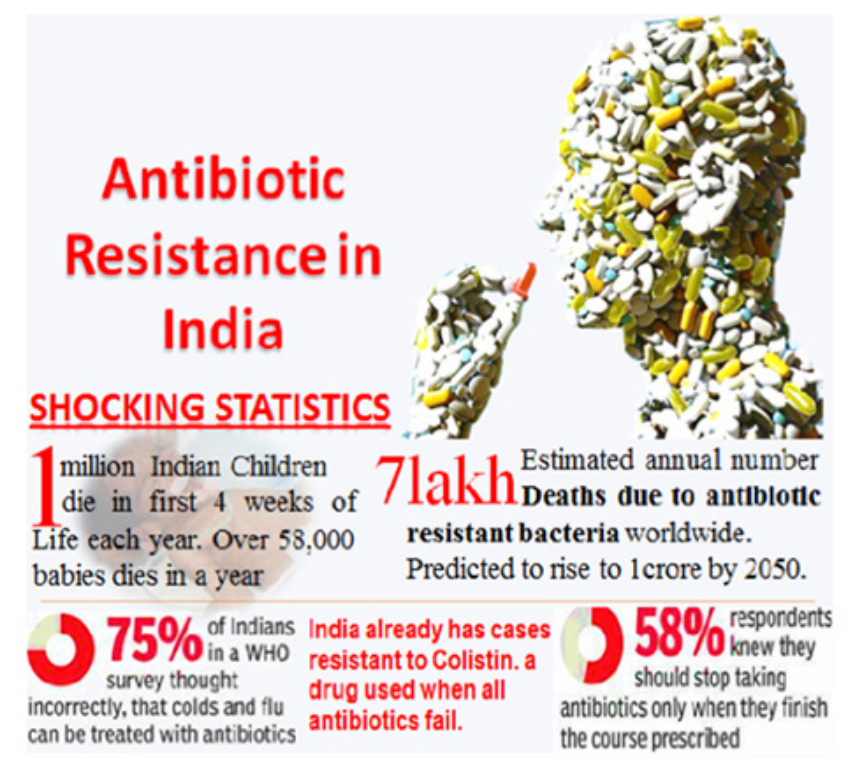

Figure 1: Shows the alarming statistics of antibiotic usage in India.

According to the centre for disease dynamics, economics \& policy (CDDEP), one million Indian children die in the first 4 weeks of life each year, of these deaths 1,90,000 are caused by a bacterial infection, sepsis that surpass the bloodstream. Out of these deaths 58,319 (over 30\%), deaths are due to antibiotic resistance. India already reported having resistance towards Colistin, an antimicrobial drug used when all other antibiotics fail.
Indian Council of Medical Research (ICMR) in recent times identified antimicrobial-resistant organisms in the digestive tracts of two out of every three healthy persons $(67 \%)$ that it tested, pointing to a quick broaden of antimicrobial resistance in the Indian population. A mix of underprivileged community health systems and hospital infection, high rates of infectious disease, and irrational use of antibiotics is impending together to increase the prevalence of resistant pathogens and is increasing the burden of untreatable neonatal sepsis and health-care-associated infections. ${ }^{14}$ The answer to the current approach to antibiotic resistance is to protect the efficiency of the drugs currently available by antibiotic stewardship and to capitalize on hospital infection-control practices, to limit the spread of resistance. Hence there is an urgent need to implement the antibiotic policy at all levels of Indian health care system. The principal aim of the hospital antibiotic policy is to diminish the morbidity and mortality due to antimicrobial-resistant infection, and to preserve the effectiveness of antimicrobial agents in the treatment and prevention of communicable diseases. Such policies are supposed to assist in reducing the spread of antimicrobial resistance, get better public health directly, benefit the population and lessen stress on the healthcare system. Lastly, ever-increasing the types and reporting of childhood vaccines presented by the government would decrease the disease burden extremely and spare antibiotics.

\section{THE RISE OF ANTIBIOTIC RESISTANCE}

The resistance to penicillin was noticed even earlier the widespread use of penicillin started. Abraham and Chain showed that $E$. coli cell extract could destroy the antimicrobial activity of penicillin by enzymatic action. ${ }^{15}$ Sir Alexander Fleming, also, had cautioned about the development of antibiotic resistance due to the overuse of antibiotic, as early as 1945, stating:

"I would like to sound one note of warning. It is not difficult to make microbes resistant to penicillin in the laboratory, and the same thing has occasionally happened in the body. The time may come when penicillin can be bought by anyone in the shops. Then there is the danger that the ignorant man may easily underdose himself and by exposing his microbes to non-lethal quantities of the drug make them resistant."

Sir Alexander Fleming: Nobel Lecture, December 11, 1945.

His cautioning has, unfortunately, turned out to be right. With the wide use of antibiotics, pathogens, which were previously sensitive to antibiotics, now started emerging resistance to many classes of antibiotics. The timeline for the development of antibiotics and antibiotic resistance is represented in Figure $2,{ }^{16}$ it indicates the increase in the antimicrobial drug resistance as the development of antimicrobial drug progressed and which may result in "Post antibiotic era" in 7-10 years from now. 


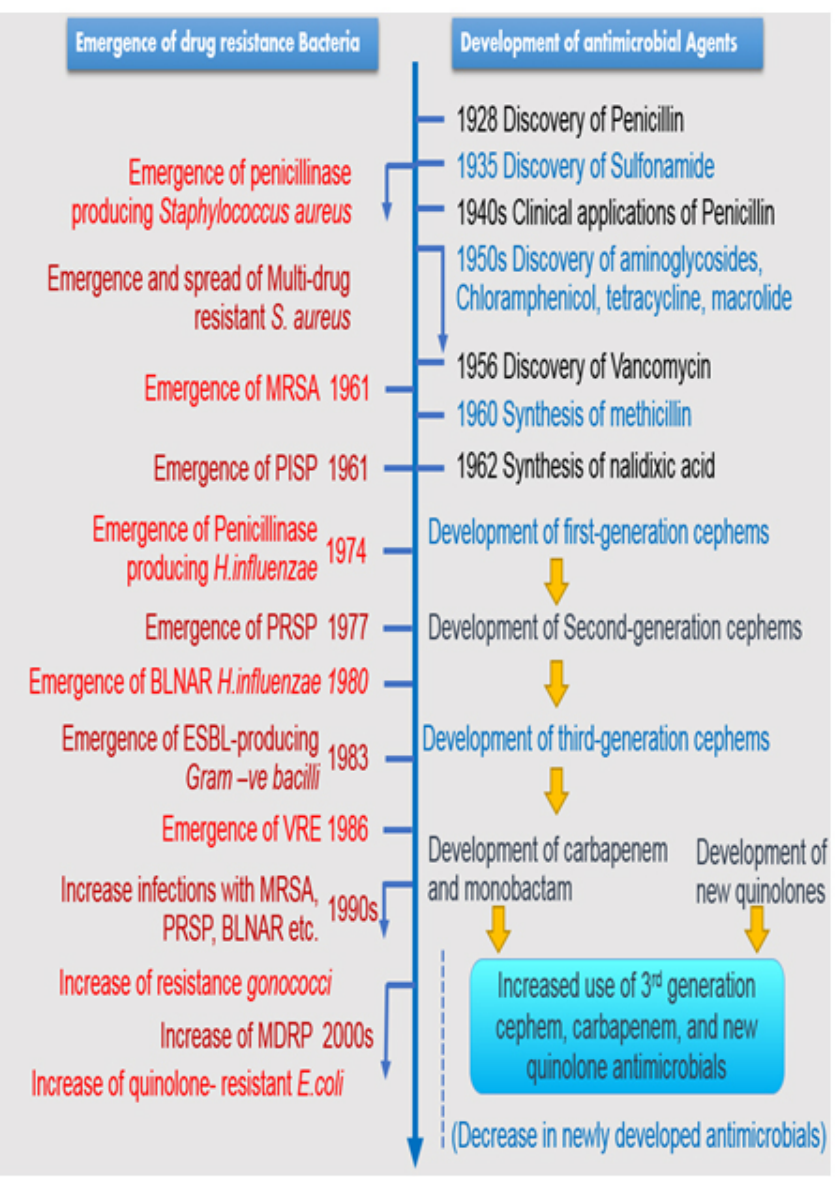

Figure 2: Orientation of development of antimicrobial agents and emergence of drugresistant. ${ }^{14}$

\section{MECHANISMS OF RESISTANCE}

Pathogenic microorganisms are becoming resistant by the mutations of pre-existing Deoxyribonucleic acid (DNA) or by the procurement of DNA comprehending antibiotic resistance genes. These resistance genes converse ranges of different antibiotic resistance mechanisms to the pathogens. Table 1 represents the diverse classes of antimicrobial agents along with their mode of action and the mechanism of resistance by microorganisms clearly shows the resistance to antibiotics can be caused by four general mechanisms (inactivation, alteration of the target, circumvention of the target pathway or efflux of the antibiotic) and an organism can develop resistance by mutating existing genes, or by acquiring new genes from other strains or species.

Table 1: Modes of action and the mechanisms of resistance of different Classes of Antibiotics

\begin{tabular}{|c|c|c|c|}
\hline $\begin{array}{l}\text { Antibiot- } \\
\text { ic class }\end{array}$ & $\begin{array}{l}\text { Representative } \\
\text { Antibiotics }\end{array}$ & $\begin{array}{l}\text { Mode of } \\
\text { action }\end{array}$ & $\begin{array}{l}\text { Mechanism of } \\
\text { Resistance }\end{array}$ \\
\hline $\begin{array}{l}\beta-\text { Lac- } \\
\text { tams }\end{array}$ & $\begin{array}{l}\text { Penicillins } \\
\text { Cephalosporins } \\
\text { Cefotaxime } \\
\text { Carbapenems }\end{array}$ & $\begin{array}{l}\text { Inhibition } \\
\text { of cell-wall } \\
\text { Synthesis }\end{array}$ & $\begin{array}{l}\text { Enzymatic deg- } \\
\text { radation of the } \\
\text { drug, Drug bind- } \\
\text { ing proteins. }\end{array}$ \\
\hline
\end{tabular}

Table 1: (Continued)

\begin{tabular}{|c|c|c|c|}
\hline $\begin{array}{l}\text { Antibiot- } \\
\text { ic class }\end{array}$ & $\begin{array}{l}\text { Representative } \\
\text { Antibiotics }\end{array}$ & $\begin{array}{l}\text { Mode of } \\
\text { action }\end{array}$ & $\begin{array}{l}\text { Mechanism of } \\
\text { Resistance }\end{array}$ \\
\hline $\begin{array}{l}\text { Amino- } \\
\text { glycosides }\end{array}$ & $\begin{array}{l}\text { Streptomycin } \\
\text { Gentamycin } \\
\text { Tobramycin Ami- } \\
\text { kacin }\end{array}$ & $\begin{array}{l}\text { Inhibition } \\
\text { of protein } \\
\text { Synthesis }\end{array}$ & $\begin{array}{l}\text { Enzymatic } \\
\text { modification, } \\
\text { efflux, ribosomal } \\
\text { mutations, } \\
\text { 16S rRNA meth- } \\
\text { ylation. }\end{array}$ \\
\hline $\begin{array}{l}\text { Quinolo- } \\
\text { nes }\end{array}$ & $\begin{array}{l}\text { Ciprofloxacin } \\
\text { Ofloxacin Nor- } \\
\text { floxacin }\end{array}$ & $\begin{array}{l}\text { Ciprofloxa- } \\
\text { cin, } \\
\text { Ofloxacin, } \\
\text { Norfloxa- } \\
\text { cin }\end{array}$ & $\begin{array}{l}\text { Efflux, modifi- } \\
\text { cation of target } \\
\text { by mutations, } \\
\text { protection of } \\
\text { target. }\end{array}$ \\
\hline $\begin{array}{l}\text { Glycopep- } \\
\text { tides }\end{array}$ & Vancomycin & $\begin{array}{l}\text { Inhibition } \\
\text { of cell-wall } \\
\text { Synthesis }\end{array}$ & $\begin{array}{l}\text { Altered cell } \\
\text { walls, drug } \\
\text { Modification }\end{array}$ \\
\hline $\begin{array}{l}\text { Tetracy- } \\
\text { clines }\end{array}$ & Tetracycline & $\begin{array}{l}\text { Inhibition } \\
\text { of Transla- } \\
\text { tion }\end{array}$ & $\begin{array}{l}\text { Efflux, modifica- } \\
\text { tion of ribosomal } \\
\text { proteins. }\end{array}$ \\
\hline $\begin{array}{l}\text { Mac- } \\
\text { rolides }\end{array}$ & $\begin{array}{l}\text { Azithromycin } \\
\text { Erythromycin }\end{array}$ & $\begin{array}{l}\text { Inhibition } \\
\text { of protein } \\
\text { Synthesis }\end{array}$ & $\begin{array}{l}\text { Enzymatic } \\
\text { modification, } \\
\text { efflux, ribosomal } \\
\text { mutations, } \\
\text { 16S rRNA meth- } \\
\text { ylation. }\end{array}$ \\
\hline $\begin{array}{l}\text { Sulfona- } \\
\text { mides }\end{array}$ & $\begin{array}{l}\text { Sulfamethoxazole } \\
\text { Trimethoprim } \\
\text { CoTrimoxazole }\end{array}$ & $\begin{array}{l}\text { Inhibition } \\
\text { of Folic } \\
\text { acid syn- } \\
\text { thesis }\end{array}$ & $\begin{array}{l}\text { Modification of } \\
\text { target }\end{array}$ \\
\hline
\end{tabular}

1) Modification of the antibiotic: The resistance can be achieved by shifting the drug molecule so that it is no more effective. This kind of resistance is observed in the case of $\beta$-lactams, macrolides and chloramphenicol. The $\beta$-lactam antibiotics are antibiotics that contain a beta-lactam ring in their molecular structure. This includes penicillin derivatives, carbapenems, cephalosporins, carbacephems, and monobactams are one of the most commonly prescribed drug classes with numerous clinical indications. The intact $\beta$-lactam ring is necessary for the action of penicillins. Bacteria produce a heterogeneous group of enzymes called $\beta$-lactamases, which cleave the $\beta$-lactam ring and inactivate the drug, thus, conferring resistance. ${ }^{15}$ Chloramphenicol resistance is usually due to inactivation of the antibiotic by chloramphenicol acetyl-transferase ${ }^{18}$ while resistance to aminoglycosides is widespread, with more than 50 aminoglycoside-modifying enzymes being discovered. ${ }^{19}$

2) Resistance by influx-efflux systems: Microorganisms have dissimilar arrangements for transport of small molecules crosswise the cell membrane. If the antibiotic does not stay in the cell, then it would not have any adverse effect. The antibiotics are flushed out of the cells by efflux pumps thus, conferring resistance. 
Resistance to fluoroquinolones and tetracyclines is commonly observed by efflux mechanism. ${ }^{17,20}$

3) Modification of the target site: If the target site is altered, it means that antibiotic cannot affect. The alterations in the antibiotic target sites can be carried out by mutation e.g., the mutation in DNA gyrase for resistance against quinolones, or enzyme modification of the target site e.g., methylation of an adenine residue in $23 \mathrm{~S}$ rRNA making it insensitive to macrolides or by replacing targets e.g., ribosomal protection proteins conferring resistance to tetracyclines. ${ }^{17,20,21}$

There are other mechanisms of resistance such as overproduction of the target gene (dihydrofolate reductase overproduction for sulfonamide resistance), target protection (qnr genes for quinolone resistance), or production of other proteins which bind to the drug and prevents the original target (penicillin-binding proteins), but the above-discussed mechanisms are the major basic mechanisms of resistance widely encountered in pathogens. ${ }^{17,20,21}$

\section{ANTIMICROBIAL RESISTANCE IN INDIA}

Development of penicillin-resistant Streptococcus pneumoniae (PRSP), methicillin-resistant Staphylococcus aureus (MRSA), multidrug-resistant Pseudomonas aeruginosa, vancomycin-resistant Enterococcus (VRE) and multidrugresistant Mycobacterium tuberculosis has led to difficulties in the treatment of infections caused by this pathogens. ${ }^{22}$ According to 'scoping report on antimicrobial resistance in India (2017), ${ }^{23}$ under the tutelage of Government of India, among the Gram-negative bacteria, above $70 \%$ isolates of Escherichia coli, Acinetobacter baumanniiand Klebsiella pneumoniae and approximately 50\% of Pseudomonas aeruginosa were resistant to fluoroquinolones and $3^{\text {rd }}$ generation cephalosporins. While the resistance to the drug combination of piperacillin-tazobactam was still below $35 \%$ for $E$. coli and $P$. aeruginosa, the existence of multiple resistance genes including carbapenemases leads to $65 \% \mathrm{~K}$. pneumoniae resistant. ${ }^{23,24}$ Increasing rates of carbapenem resistance, $71 \%$ for $A$. baumannii led to the frequent use of colistin as the last resort antimicrobial. ${ }^{23}$ The percentage of resistance among Salmonella Typhi was $28 \%$ and Shigella specieswas $82 \%$, respectively, for ciprofloxacin, $0.6 \%$ and $12 \%$ for ceftriaxone and $2.3 \%$ and $80 \%$ for co-trimoxazole. For Vibrio cholerae, resistance rates to tetracycline varied from 17 to $75 \%$ in different parts of the country. ${ }^{23,24}$ Recently, high mortality rates are detected due to multidrug-resistant bacterial infections. Each year, around 410,000 people die in India from infection with multidrug-resistant. ${ }^{11}$

The drug susceptibility study results of various laboratories in India disclose an increasing trend of development of resistance to commonly used antibiotics in pathogens like Salmonella, Shigella, Vibrio cholerae, Staphylococcus aureus, Neisseria gonorrhoeae, N. meningitidis, Klebsiella, Mycobacterium tuberculosis, HIV(human immunodeficiency virus), plasmodium and others. ${ }^{25}$ New resistance mechanisms, such as the Metallo beta-lactamase NDM-1 (New Delhi Metallo betalactamase 1), have developed among several gram-negative bacilli. This can render powerful antibiotics ineffective, which are often used as the last line of defence against multi-resistant strains of bacteria. ${ }^{3}$ Table 2 shows the various studies on antimicrobial resistance in India. Due to the Extended-spectrum beta-lactamases (ESBL), multidrug-resistant entero bacteriaceae, have become very frequent in India. Besides, different studies in South India highlighted the resistance pattern like Ciprofloxacin resistant Salmonella enteric serovar Typhi, multidrug-resistant Extended-Spectrum $\beta$-Lactamase Producing Klebsiella pneumoniae, fluoroquinolone resistance among Salmonella enteric serovar Paratyphi A, the emergence of vancomycin-intermediate staphylococci, Pseudomonas aeruginosa and Acinetobacter baumannii resistant to ceftazidime, cefepime and ciprofloxacin. The resistance to colistin has also developed in India. Although the percentage of colistin resistance was below one, high mortality of $70 \%$ was associated with colistin-resistant $K$. pneumoniae. Amongst the Grampositive organisms, $42.6 \%$ of Staphylococcus aureus were methicillin-resistant and $10.5 \%$ of Enterococcus faecium were vancomycin-resistant. ${ }^{26,27}$

Table 2: Antibiotic resistance rates of various organisms in India during Last two decades

\begin{tabular}{|c|c|c|c|c|}
\hline S. No & $\begin{array}{l}\text { Type, number and Loca- } \\
\text { tion of Isolates }\end{array}$ & $\begin{array}{l}\text { Name of the microor- } \\
\text { ganism }\end{array}$ & Resistance rate \% & $\begin{array}{l}\text { Author and Ye: } \\
\text { Reported }\end{array}$ \\
\hline 1 & $\begin{array}{l}338 \text { Urinary isolates } \\
\text { @ Armed Force Medical } \\
\text { College (AFMC), Pune }\end{array}$ & $\begin{array}{l}\text { E. coli } \\
\text { Proteus spp } \\
\text { K. pneumoniae }\end{array}$ & $\begin{array}{l}81 \% \text { to Ampicillin, } \\
23 \% \text { to Cefotaxime } \\
89 \% \text { to Ampicillin, } \\
82 \% \text { to Ofloxacin } \\
\text { 100\% to Sulphamethoxazole\& Trimeth- } \\
\text { oprim. }\end{array}$ & $\begin{array}{l}\text { RN Mishra et al. } \\
(1999)^{28}\end{array}$ \\
\hline 2 & $\begin{array}{l}63 \text { sputum isolates } \\
@ \text { Christian Medical College }\end{array}$ & $\begin{array}{l}\text { Mycobacterium tuber- } \\
\text { culosis }\end{array}$ & $\begin{array}{l}49 \% \text { to Isoniazid, } 35 \% \text { to Rifampicin, } \\
25 \% \text { to Streptomycin. }\end{array}$ & $\begin{array}{l}\text { Kenneth A et al. } \\
(2000)^{29}\end{array}$ \\
\hline
\end{tabular}

Hospital (CMCH), Vellore 
Table 2: (Continued)

$\begin{array}{ll}\text { S. No } & \begin{array}{l}\text { Type, number and Loca- } \\ \text { tion of Isolates }\end{array} \\ 3 & \begin{array}{l}\text { Single isolate } \\ \text { @ CMCH, Vellore }\end{array} \\ 4 \quad \begin{array}{l}30 \text { Burn skin swab isolates } \\ \text { @ Aligarh }\end{array} \\ \\ \text { 1175 clinical isolates } \\ \text { @AFMC, Pune } \\ 6 \quad \begin{array}{l}158 \text { clinical isolates } \\ \text { @Kolkata }\end{array} \\ \text { Clinical isolates collected } \\ \text { between 1995-20o1 @ New } \\ \text { Delhi }\end{array}$

Name of the microor- Resistance rate \% ganism

S. pneumoniae

P. aeruginosa

Acinetobacter species

Aeromonascaviae

Staphylococcus aureus

Escherichia coli

Pseudomonas aerugi-

nosa

13

14
Clinical Isolates @Sant Parmanand Hospital, Delhi

2995 clinical isolates @ Lucknow

3984 clinical isolates @ AIIMS, Delhi

61 isolates During the cholera epidemic @ Hubli

9858 clinical isolates @ Delhi

284 clinical isolates @ Kolkata

\section{1 clinical isolates @ Pu-} ducherry

1300 isolates from nasopharyngeal swabs @ Nagpur

61 isolates from 176 clinical specimens @CMC, Vellore

83 clinical isolates @Mangalore

Escherichia coli

Klebsiellaspp

Pseudomonas.

Vibrio cholerae

V.cholera

metallo-beta-

lactamase $(M B L)$

producing bacteria

Klebsiella spp.

Staphylococcus spp.

MR-S.aureus

P. aeruginosa

Community associated $M R-S$. aureus

Enterococcal strains

$$
\text { Mangalore }
$$

3984 clinical isolates @ AIIMS, Delhi

337 blood culture isolates @ Pondicherry

Pseudomonas spp.

Acinetobacter spp.

Klebsiella Spp.

E. Coli

Enterobacter spp.

Gram Positive

S.aureus

staphylococci $56.7 \%$ to Amikacin floxacin Penicillin,

(2001) for Amikacin

$40 \%$ to Ceftriaxone

$57 \%$ to Amoxicillin

$63 \%$ to Amoxicillin

$56 \%$ to Norfloxacin

Nalidixic Acid Gentamycin) cillin

$72 \%$ to Oxacillin

4.16\% to Methicillin

nations

$85 \%$ to Methicillin
First confirmed isolate resistant to cefotaxime \&erythromycin

83.3\% Multidrug-Resistant

$69.7 \%$ Multidrug-Resistant, $77 \%$ to Sulphamethoxazole\& Trimethoprim, 80\% to Ampicillin $75 \%$ to Nalidixic Acid

$53 \%$ to Nalidixic Acid \& $30 \%$ to Cipro-

Increased from 55\% (1995) to 90\% for

Increased from $55 \%$ (1995) to $82 \%$

(2001) for Amoxyclav,

Increased from $20 \%$ (1995) to $49 \%$

$47 \%$ to Ciprofloxacin

96\% to Furazolidone, Cotrimoxazole \&

$43.3 \%$ to 7 Antibiotics (Ampicillin, Amoxicillin, Cephalexin, Ciprofloxacin, Cotrimoxazole, Erythromycin \&

98\% to Ampicillin, Ticarcillin \& Pipera-

Jain A

42.6\% to Carbapenem

Author and Year

Reported

MK Lalitha

et al. (2002) $)^{30}$

Shahid M

et al (2003) $)^{31}$

K Lahiri

et al. $(2004)^{32}$

Sinha S

et al. (2004) ${ }^{33}$

Wattal C

et al. (2005) ${ }^{34}$

Subhash

et al. (2006) ${ }^{35}$

Krishna

et al. (2006) $)^{36}$

Sharma NC

et al. $(2007)^{37}$

Arora RS

et al. $(2007)^{38}$

et al. (2007) 39

Menezes GA

et al. (2008) ${ }^{40}$

Chande CA

et al. (2009) ${ }^{41}$

Manoharan A

et al. (2010) $)^{42}$

93\% to Penicillin \& $31 \%$ to Erythromycin Shenoy MS

et al. (2010) $)^{43}$

$17-43 \%$ to Aminoglycosides

Adhikari L (2010) $)^{44}$

50\% to Carbapenems

$66 \%$ to Aminoglycosides

$76 \%$ to Fluoroquinolones

$88 \%$ to third generation Cephalosporins

$66 \%$ to Betalactamese inhibitor combi-

22\% Multidrug Resistant

78\% Nalidixic Acid Resistant
Behera B

Behera B

et al. (2011) 45

et al. (2011) 45

Menezes

et al. (2012) $)^{46}$ 
Table 2: (Continued)

\begin{tabular}{|c|c|c|c|c|}
\hline S. No & $\begin{array}{l}\text { Type, number and Loca- } \\
\text { tion of Isolates }\end{array}$ & $\begin{array}{l}\text { Name of the microor- } \\
\text { ganism }\end{array}$ & Resistance rate \% & $\begin{array}{l}\text { Author and Year } \\
\text { Reported }\end{array}$ \\
\hline 21 & $\begin{array}{l}\text { 1140 blood culture isolates } \\
\text { @ NICU, Delhi }\end{array}$ & $\begin{array}{l}\text { Klebsiella spp. } \\
\text { S aureus and } \\
\text { E. coli }\end{array}$ & $\begin{array}{l}72 \% \text { to Ceftriaxone } \\
63 \% \text { to Meropenem } \\
70 \% \text { to Ciprofloxacin }\end{array}$ & $\begin{array}{l}\text { Jyoti B } \\
\text { et al. }(2013)^{47}\end{array}$ \\
\hline 22 & $\begin{array}{l}3771 \text { blood culture isolates } \\
\text { @ tertiary care hospital, } \\
\text { North India }\end{array}$ & $\begin{array}{l}\text { E. coli } \\
\text { Klebsiella spp. } \\
\text { S. aureus } \\
\text { Enterococcus spp. }\end{array}$ & $\begin{array}{l}\text { MDR, } 96 \% \text { to Ampicillin, } \\
\text { MDR, } 95 \% \text { to Ceftazidime } \\
100 \% \text { to Penicillin } \\
84 \% \text { to Gentamicinı2o }\end{array}$ & $\begin{array}{l}\text { Chand Wattal } \\
\text { et al. }(2014)^{48}\end{array}$ \\
\hline 23 & $\begin{array}{l}92 \text { isolates from circulating } \\
\text { clones in Bangalore }\end{array}$ & $\begin{array}{l}\text { Staphylococcus aureus } \\
(S A)\end{array}$ & $\begin{array}{l}54 \% \text { to Erythromycin } \\
71 \% \text { to Ciprofloxacin }\end{array}$ & $\begin{array}{l}\text { C. Bouchiat } \\
\text { et al. }(2015)^{49}\end{array}$ \\
\hline 24 & $\begin{array}{l}7131 \text { blood culture isolates } \\
\text { @Delhi Neonatal Infection } \\
\text { Study }\end{array}$ & $\begin{array}{l}\text { Acinetobacter spp } \\
\text { Klebsiella spp } \\
\text { E coli }\end{array}$ & $\begin{array}{l}\text { High rates of multidrug resistance } \\
(40-81 \%) \\
\text { Emerging resistance to Colistin is ob- } \\
\text { served }(1 \%)\end{array}$ & $\begin{array}{l}\text { Agrawal R } \\
\text { et al. }(2016)^{50}\end{array}$ \\
\hline 25 & $\begin{array}{l}18695 \text { clinical isolates @27 } \\
\text { states (including two UTs) }\end{array}$ & $\begin{array}{l}\text { Escherichia coli } \\
\text { Enterococcus faecium }\end{array}$ & $\begin{array}{l}85 \% \text { to Fluoroquinolones } \\
3 \% \text { to Colistin } \\
97 \% \text { to Ampicillin } \\
32 \% \text { to Vancomycin }\end{array}$ & $\begin{array}{l}\text { Gandra S } \\
\text { et al. }(2016)^{5^{1}}\end{array}$ \\
\hline 26 & $\begin{array}{l}77 \text { clinical isolates @ J.N. } \\
\text { Medical College, Aligarh }\end{array}$ & $\begin{array}{l}\text { Staphylococcus aureus } \\
\text { P. aeruginosa }\end{array}$ & $\begin{array}{l}83 \% \text { to Clindamycin } \\
75 \% \text { to Ofloxacin } \\
79 \% \text { to Cefepime } \\
81 \% \text { to Ofloxacin }\end{array}$ & $\begin{array}{l}\text { Gupta R } \\
\text { et al. }(2017)^{52}\end{array}$ \\
\hline 27 & $\begin{array}{l}1103 \text { clinical isolates @ } \\
\text { tertiary-care hospital in } \\
\text { Eastern India }\end{array}$ & Klebsiella pneumoniae & $\begin{array}{l}45 \% \text { Extensively drug-resistant } \\
28 \% \text { Pandrug-resistant } \\
16 \% \text { to Colistin } \\
52 \% \text { to Tigecycline }\end{array}$ & $\begin{array}{l}\text { Mohapatra DP et al. } \\
(2018)^{53}\end{array}$ \\
\hline 28. & $\begin{array}{l}2499 \text { clinical isolates @ } \\
\text { multi-speciality ICU, Lu- } \\
\text { dhiana }\end{array}$ & $\begin{array}{l}\text { Klebsiella spp } \\
\text { Acinetobacter spp. }\end{array}$ & $\begin{array}{l}9 \% \text { to Colistin } \\
60 \% \text { to Cefoperazone } \\
3 \% \text { to Colistin }\end{array}$ & $\begin{array}{l}\text { Sodhi K } \\
\text { et al. }(2019)^{26}\end{array}$ \\
\hline 29. & $\begin{array}{l}\text { 6o clinical isolates ocular } \\
\text { infection @ Eye Institute, } \\
\text { Bhubaneswar }\end{array}$ & $\begin{array}{l}\text { Serratia } \\
\text { Marcescens } \\
\text { Burkholderiacepacia }\end{array}$ & $\begin{array}{l}13 \% \text { to Colistin } \\
11 \% \text { to Colistin }\end{array}$ & $\begin{array}{l}\text { Mitra S } \\
\text { et al. }(2020)^{27}\end{array}$ \\
\hline
\end{tabular}

\section{CHALLENGES OF AMR IN INDIA}

India has been raised as 'the AMR capital of the world'. ${ }^{54}$ Whereas, development of newer multi-drug resistant (MDR) organisms posture newer diagnostic and therapeutic challenges, while India is still striving to combat old enemies such as tuberculosis, malaria and cholera pathogens, which became more and more drug-resistant. Factors such as poverty, illiteracy, overcrowding and malnutrition additional compound the situation..$^{55}$ Lack of awareness about infectious diseases in the common people and inaccessibility to healthcare frequently prevent them from seeking medical guidance. This, often, leads to self-prescription of antibiotics without any expert knowledge about the dose and duration of treatment. ${ }^{56}$ Patients who seek medical guidance, many end up consuming broad-spectrum high-end antibiotics due to lack of appropriate diagnostic modalities for identifying the pathogen and its drug susceptibility. Low doctor to patient and nurse to patient ratios along with lack of infection prevention and control (IPC) guidelines favour the spread of MDR organisms in the hospital settings. ${ }^{13,55}$ Easy accessibility of over the counter (OTC) drugs. ${ }^{57}$ additional contributes to antimicrobial resistance. Also, the increase in the pharmaceutical segment has triggered a corresponding increase in the amount of waste generated by these firms. With the absence of firm controlling and legal actions, this waste reaches the water bodies and serves as a continuous source of AMR in the environment. ${ }^{13,58}$ Another important challenge is the use of antimicrobial agents as pesticides and insecticides in the agriculture industry, while the evidence for the same is inadequate currently. ${ }^{59}$

\section{CONSEQUENCES OF RESISTANCE}

Antibiotic resistance had a great impact on health and wealth consequences. Increase in the resistance results in a decrease in the patient outcome and increase in the cost of pharmacy. 
According to most recent study resistance developed patients had an increase in intensive care admission and long duration of stay in hospitals. There is also an increase in the mortality rate of the patients admitted with antibiotic resistance. Bacterial resistance makes the therapeutic dilemma to clinicians. ${ }^{15}$ However, the rules for controlling the sale of antibiotics worldwide, but particularly in developing countries, are weak, thus making it necessary to establish more rigorous preventive actions to control the side effects of infections that are resistant to antibiotics (usually unnecessarily prescribed) or even multi-drug-resistance (MDR) ${ }^{60}$ MDR, defined as antimicrobial resistance to at least one agent across three or more antimicrobial categories, results from one of two mechanisms ${ }^{61}$ multiple genes accumulated by bacteria, each coding for resistance to a single drug within a single cell, ${ }^{62}$ and increased expression of genes that code for multidrug efflux points. ${ }^{63,64}$ The prevalence of MDR has been reported as ranging from $4 \%$ to $20 \%$, with higher prevalence in nosocomial infections. MDR affects both Gram-positive and Gram-negative bacteria, but therapeutic options are more limited for the latter. MDR is a major global public health concern, magnified by antibiotic overuse and unwarranted prescribing antibiotics. The use of inappropriate empiric antimicrobials increases the risk of MDR and mortality. ${ }^{7}$

Antibacterial drugs have been misused in humans for several decades, thereby creating ways for selection and spread of drug-resistant bacteria. Consequently, antibacterial drugs have become less effective or even ineffective, resulting in an accelerating global health security emergency that is rapidly outpacing the availability treatment options. WHO reports identify Staphylococcus aureus resistance to betalactam antibacterial drug methicillin as an international concern. ${ }^{65}$ Excess usage of antibiotics has expedited the development of methicillin resistance in $S$. aureus (MRSA). Risk of death in patients infected with MRSA is as high as 26.3\%. Antibacterial resistance by MRSA also causes additional medical costs for antibacterial therapy, medical care and additional cost variable. ${ }^{66}$ MRSA strains identified four decades ago have become more problematic due to the evolutionary mechanisms adapted by the bacteria to evade antibiotics which are supported by environmental changes which aid the bacterial spread beyond the restrictions of health care facilities. Virulence conferred by these factors rendered the bacterium dominant resulting in making significant changes in the choice of antibiotics for the management of community-acquired infections. ${ }^{67}$

Compared with the abrupt contests of HIV/AIDS, tuberculosis, malaria, pneumonia, and many other communicable diseases, the loss of antibiotics at some future time does not capture the same consideration. Resistance in contradiction of certain antibiotics is already at high levels in certain places in India (and around the world), but the problem has persisted largely unidentified because comparatively few studies were available and countrywide observation was not being carried out. But the issue came to the fore in India when New Delhi Metallo-í-lactamase-1 (NDM-1), first reported in 2009 , made front-page news in $2010^{5}$. Briefly, NDM-1 is an enzyme produced by the gene blaNDM-1; it is named for New Delhi because the Swedish patient in whom it was first identified had undergone surgery in a New Delhi hospital. ${ }^{68}$ NDM-1 may be the most widely known form of antibiotic resistance in India, but several studies in recent years have documented significant rates of resistance to a wide range of antibiotics. Many are of hospital-acquired Gram-negative infections with Acinetobacter, Pseudomonas, Klebsiella, E. coli and gonorrhoeae. ${ }^{69,70}$

Comparable studies on the rise of antimicrobial resistance in gram-positive and gram-negative bacteria are reported also from India. The resistance array varies widely reliant on the type of the geographical location and health care setting, availability of antibiotics in hospitals and over the counter, prescribing habits of treating clinicians coming from different streams of medicine like allopathy, ayurvedic, homoeopathy or quacks. The drug resistance has been reported to develop in a population to an antibiotic molecule following its improper and irrational use. Irrespective of whether NDM-1 turns out to impend patients' health in India, the attention focused on this pathogen has encouraged the Government to act on antibiotic resistance. As an outcome, a Ministry of Health and Family Welfare task force declared a new national anti-microbial policy. ${ }^{71}$

\section{ANTIBIOTIC POLICY}

The terms antibiotic guidelines and policy are frequently used interchangeably and may be unclear to many healthcare professionals. An antibiotic policy is a set of ideologies to guide the execution of prudent and rational antimicrobial prescribing in the healthcare system. Antibiotic guidelines are detailed endorsements for antibiotic treatment or prophylaxis for particular infections, diseases or syndromes. ${ }^{72}$ The antibiotic policy is the set of approaches and events commenced to establish the antimicrobial treatment in the hospital and reach health outcomes for patients. The straightforward ideologies are to be direct evidence-based medicine, local epidemiology and liberty for prescribing physicians. An antibiotic policy is now more mandatory than ever for clinical, epidemiological and economic reasons. The Infection Committee is responsible for the antibiotics policy in hospitals. ${ }^{73}$ The primary aim of the hospital antimicrobial policy is to diminish the morbidity and mortality due to antimicrobial-resistant infection, and to preserve the efficiency of antimicrobial agents in the treatment and deterrence of communicable diseases. The antibiotic policy is fundamentally for prophylaxis, definitive and empirical therapy. The policy shall include detailed endorsements for the treatment 
of diverse high-risk/special groups such as immunocompromised hosts; community-associated infections and hospitalassociated infections. It ought to similarly set the stages for recommending antibiotics; for instance, first-choice antibiotics can be prescribed by all doctors while restricted choice antibiotics can only be prescribed after consulting the antimicrobial team (AMT) representative or the head of the department. Reserve antibiotics, conversely, are prescribed only by designated experts. ${ }^{74}$

\section{ATTRIBUTES OF ANTIBIOTIC POLICY}

The policy should be simple, clear, clinically appropriate, flexible and pertinent to day-to-day practice and accessible in user-friendly presentation such as a pocket guide, webbased form, etc. The recommended antibiotic should be effective against pathogens often seen in that locality. ${ }^{72}$ Guidelines should be provided for optimal selection, dosage, route of administration, duration, and alternatives for allergy to first-line agents; and for adjusted dosage for patients with impaired liver or renal function. Recommendation for prophylactic use should specify procedures for which antibiotic are needed, optimal agents, dosage, timing, route and duration of administration so that adequate antibiotic concentrations are available at the time of bacterial contamination. Prophylaxis recommendation should mainly focus on clean as well as contaminated procedures. The prophylactic dose is recommended for a short duration, free of side-effects, and should be relatively cheap. Also, the antibiotics selected for prophylaxis should not be used therapeutically; as this may lead to the emergence of antimicrobial resistance. ${ }^{74}$

It will take substantial effort, time and resources to formulate antibiotic policies and guidelines from the scratch in this situation. It is worthwhile to go through the other guidelines that are pertinent to the local condition in the hospital setting or country and adapt accordingly. A multidisciplinary antibiotic administration team can be set up to engrave the antibiotic policy and guideline in hospital and the team includes surgeons, physicians, paediatricians, clinical microbiologists and pharmacists. ${ }^{43}$ And the policy should recommend the principles of antimicrobial stewardship, antibiotics for general use, reserved and restricted antibiotics; replacements for antibiotic use in case of allergy, guidance for the route of administration like intravenous to oral switch etc. Further, the guideline should also provide information on the diseased/ syndrome e.g. pneumonia; type of clinical setting - inpatient units, outpatient clinics, ICU setting; when to switch from IV to oral and measures for the finding of infection/syndrome. The policy and guideline should be clear, simple, appropriate to day to day practice, relevant to local clinical conditions and available in suitable formats. The antibiotic guidelines and policy are alive documents and consequently should be revised at regular intervals. They should be modernized con- ferring to current medical information, medical practice and local circumstances. ${ }^{75}$

\section{HOSPITAL VERSUS NATIONAL ANTIBIOTIC POLICY}

Generally, the hospital antibiotic policy should concur or align with the national antibiotic policy except for a few changes as warranted by the local antimicrobial resistance profiles. If there is a wide variation from national to hospital, and hospital to hospital then the desired purpose is defeated i.e., to minimize the morbidity and mortality due to antimicrobial-resistant infections; to preserve the effectiveness of antimicrobial agents in the treatment and to prevent microbial infections. ${ }^{74}$ A national antibiotic policy should address all relevant issues for antibiotic use, both in the community and the hospital, including veterinary and agricultural use.

The National Policy for Containment of Antimicrobial Resistance - India covers a range of topics, including curbing antibiotic use in animals, particularly those raised for human consumption; conducting infection surveillance in hospitals; improving hospital surveillance for monitoring antibiotic resistance; promoting rational drug use through education, monitoring, and supervision; researching new drugs; and developing and implementing a standard and more restrictive antibiotic policy. Under the new Schedule H1 (now called HX), which will regulate antibiotic use, selling antibiotics over the counter will be banned. Certain antibiotics, including carbapenems, will be available at only tertiary hospitals. ${ }^{71}$

\section{IMPLEMENTATION OF ANTIBIOTIC POLICIES}

Antibiotic policy contributes to the optimization of antimicrobial therapy, ensuring the proper use (indication, dose and duration) and minimizing side effects. ${ }^{76}$ An adoption of these kinds of policies leads to a reduction in the prevalence of antimicrobial resistance, costs and save lives. ${ }^{77}$ In 2015 Canter for Disease Control and Prevention (CDC) published a report about core elements of hospital antibiotic stewardship programs. ${ }^{78}$ According to CDC "there is no single template to optimize antibiotic usage". The medical decision is complex and the antibiotic implementation policies should be flexible. Therefore, there is a need for defined leadership and coordinated multidisciplinary approach. ${ }^{78}$ For ideal decision making in prescribing antibiotics, doctors essentially have adequate information about infectious diseases, infecting microbes, and antimicrobials. So, the leader of the program should be infectious disease expert or infectious disease professional should co-direct the program with a clinical pharmacist. Thus, the key members of an antimicrobial stewardship team are constituted. ${ }^{79}$ For antimicrobial resistance investigation a clinical microbiologist, and the computer support an information system specialist is also needed. ${ }^{80}$ 
The infectious diseases physician or a clinical pharmacist with infectious diseases training has to have interactions with the prescriber physicians. They should perform a prospective audit and a feedback system, serving to reduce the inappropriate use of antimicrobials. ${ }^{79,80}$

In India, National Centre For Disease Control, under Directorate General of Health Services, Ministry of Health \& Family Welfare, has formulated National Treatment Guidelines for Antimicrobial Use in Infectious Diseases in the year 2016 to combat emerging Antimicrobial resistance in India ${ }^{71}$, and the implementation in the hospital level is lagging. As per data available from NABH assessor's conclave most accredited hospitals, though having a well written antibiotic policy on paper, are not compliant in practice. And so far, no hospital is maintaining a separate register for the use of antibiotics up to the mark. In a recent study antibiotics usage in an intensive care ICU are more expensive that has to be concerned and there is a need to follow the guidelines to be followed in using them which clearly states that the policies and guidelines for antibiotics used in the country are not efficient practice. India, with more than 20,000 hospitals, more than a billion population, wide cultural diversity, socio-economic disparity, and a large medical community of more than threefourths of a million doctors, will find the resistance problem an issue very difficult to tackle. Hence the government, policymakers and stakeholders should initiate the strategies to reduce the economic burden on the patient by developing and implementing the antibiotic policies in Indian healthcare settings like the primary, secondary and tertiary hospital to combat Antimicrobial resistance. To implement antibiotic usage as per the developed policies in India the national Action plan of the government should develop information, educate the physicians and the patients and training should be given on the usage of policies.

\section{CONCLUSION}

In summary, the choice of suitable antimicrobial depends on an understanding of the prospective pathogens and local vulnerability patterns. In selecting the right antibiotics, the properties of the antimicrobials; such as Pharmacokinetics and Pharmacodynamic (PK and PD) profiles, mechanism of action and strength, permissibility and safety, are all important factors. ${ }^{81}$ Initial suitable antibiotic treatment has been shown to reduce mortality, the span of stay in ICU and hospital. Early correct antibiotic chooses have also served to the reduction in antimicrobial costs. ${ }^{82}$ In this reverence, it is emphasized that infectious disease specialist service being a professional in the arena, plays a significant part in improving antimicrobial usage, by advising on the judicious use of antimicrobial agents and by developing evidence-based guidelines under the light of antibiotic implementation policies. $^{83,84}$ Therefore it is essential to develop Antibiotic policy in every Indian health care system and implement it properly by educating and training the infectious disease specialist. All hospitals must have an infection control committee (ICC) and an antibiotic policy and should initiate or augment efforts towards implementation. Those hospitals with an existing ICC and an antibiotic policy should augment efforts to increase compliance with the policy. Hospitals without a policy must initiate efforts to formulate an ICC and an antibiotic policy. The Government of India and respective state governments should take initiative to develop the antibiotic policy at every public care hospital to decrease the morbidity and mortality due to antimicrobial-resistant infection, and to preserve the efficiency of antimicrobial agents in the treatment and prevention of communicable diseases.

\section{ACKNOWLEDGEMENT}

Authors wish to thank JSS College of Pharmacy, Ooty and JSS Academy of Higher Education \& Research, Mysuru for providing all the necessary facilities and support to write this article. We also thank physicians/consultants of Govt. Medical College Hospital, Ooty for providing the necessary inputs and corrections of this manuscript.

\section{Conflict of Interest: None}

\section{Source of Funding: None}

\section{REFERENCES}

1. Verma S, Prakash V, Prasad KN, Dhol TN. High rates of antibiotic drug resistance among gram-negative bacilli in lower respiratory tract infections in north India. Int J Curr Res Rev 2016;8(14):9

2. Deotale VS, Attal R, Narang P. Increase in antibiotic resistance: are bacteria growing with pan resistance? Int J Curr Res Rev $2015 \mathrm{Feb} ; 7(3): 43$.

3. Kumar SG, Adithan C, Harish BN, Sujatha S, Roy G, Malini A. Antimicrobial resistance in India: A review. J Nat Sci Biol Med 2013 Jul;4(2):286-291.

4. World Health Organization Staff, World Health Organization. Cancer pain relief: with a guide to opioid availability. World Health Organization; 1996.

5. Ganguly NK, Arora NK, Chandy SJ, Fairoze MN, Gill JP, Gupta $\mathrm{U}$, et al. Rationalizing antibiotic use to limit antibiotic resistance in India. Indian J Med Res 2011 Sep;134(3):281-94.

6. Auta A, Hadi MA, Oga E, Adewuyi EO, Abdu-Aguye SN, Adeloye D; Global access to antibiotics without prescription in community pharmacies: A systematic review and meta-analysis. J Infect 2019; 78(1):8-18.

7. Juárez-Hernández E, Uribe M. The lack of guidelines and government policies for regulating nonprescription sale of antibiotics and its medical consequences; Ann Hepatol 2019;18(6);783-785.

8. Austin DJ, Kristinsson KG, Anderson RM. The relationship between the volume of antimicrobial consumption in human communities and the frequency of resistance. PNAS 1999;96:11521156.

9. Laxminarayan R, Malani A. Extending the cure: policy responses to the growing threat of antibiotic resistance. Earthscan; 2007. 
10. World Health Organization. World health statistics 2015. World Health Organization; 2015 May 14.

11. Mathew JL. Pneumococcal vaccination in developing countries: Where do science end and commerce begin? Vaccine $2009 \mathrm{Jul}$ 9;27(32):4247-4251.

12. Levine OS, Cherian T. Pneumococcal vaccination for Indian children. Indian Paediatr 2007;44(7):491.

13. Laxminarayan R, Chaudhury RR. Antibiotic Resistance in India: Drivers and Opportunities for Action. PLoS Med 2016;13(3):e1001974.

14. Laxminarayan R, Matsoso P, Pant S, Brower C, Røttingen JA, Klugman $\mathrm{K}$, et al. Access to effective antimicrobials: a worldwide challenge. Lancet 2016;387(10014), 168-175.

15. Abraham EP, Chain E. An enzyme from bacteria able to destroy penicillin. Nature 1940 Dec;146(3713):837-845.

16. Saga T, Yamaguchi K. History of antimicrobial agents and resistant bacteria. JMAJ 2009 Mar;52(2):103-108.

17. Jayaraman, R; Antibiotic resistance: an overview of mechanisms and a paradigm shift. Curr Sci 2009;96(11):1475-1484.

18. Trieu-Cuot P, De Cespedes G, Bentorcha F, Delbos F, Gaspar E, Horaud T. Study of heterogeneity of chloramphenicol acetyltransferase (CAT) genes in streptococci and enterococci by polymerase chain reaction: characterization of a new CAT determinant. Antimicrobial agents and chemotherapy. 1993;37(12):2593-2598.

19. chmitz, FJ and Fluit. AC 1999. Mechanisms of resistance. In Infectious Diseases ed D. Armstrong, and S. Cohen, pp. 7.2.17.2 .14

20. Byarugaba DK. Mechanisms of antimicrobial resistance. InAntimicrobial Resistance in Developing Countries 2010 (pp. 1526). Springer, New York, NY.

21. Aminov RI. A brief history of the antibiotic era: lessons learned and challenges for the future. Front Microbiol 2010;1:134.

22. Dulon M, Haamann F, Peters C, Schablon A, Nienhaus A. MRSA prevalence in European healthcare settings: a review. BMC Infect Dis 2011;11(1):138.

23. Gandra S, Joshi J, Trett A, Lamkang A, Laxminarayan R. Washington, DC: Center for Disease Dynamics, Economics \& Policy; 2017. Scoping Report on Antimicrobial Resistance in India.

24. Taneja N, Sharma M. Antimicrobial resistance in the environment: The Indian scenario. Indian J Med Res 2019;149(2):119128.

25. World Health Organization. Prevention and containment of antimicrobial resistance. Report of a regional meeting Chiang Mai, Thailand, 8th to 11th of June 2010.

26. Sodhi K, Mittal V, Arya M, Kumar M, Phillips A, Kajla B. Pattern of colistin resistance in Klebsiella isolates in an Intensive Care Unit of a tertiary care hospital in India. J Infect Public Health 2020 Jul;13(7):1018-1021.

27. Mitra S, Basu S, Rath S, Sahu SK. Colistin resistance in Gramnegative ocular infections: prevalence, clinical outcome and antibiotic susceptibility patterns. Int Ophthalmol 2020;23:1-13.

28. Misra RN, Debata NK, Chander Y, Ohri VC. Changes in urinary isolates and their antibiotic resistance pattern. Med J Armed Forces India 1999;55(2):115-118.

29. Harris Jr KA, Mukundan U, Musser JM, Kreiswirth BN, Lalitha MK. Genetic diversity and evidence for acquired antimicrobial resistance in Mycobacterium tuberculosis at a large hospital in South India. Int J Infect Dis 2000;4(3):140-147.

30. Lalitha MK, Pai R, Manoharan A. Multidrug-resistant Streptococcus pneumoniae from India. Lancet 2002;359(9304):445.

31. Shahid M, Malik A. Multidrug-resistant Pseudomonas aeruginosa strains harbouring R-plasmids and AmpC $\beta$-lactamases isolated from hospitalised burn patients in a tertiary care hospital of North India. FEMS Microbiol Lett 2003;228(2):181-186.
32. Lahiri KK, Mani NS, Purai SS. Acinetobacter spp as a nosocomial pathogen: Clinical significance and antimicrobial sensitivity. Med J Armed Forces India 2004;60(1):7-10.

33. Sinha S, Chattopadhyay S, Bhattacharya SK, Nair GB, Ramamurthy T. An unusually high level of quinolone resistance associated with type II topoisomerase mutations in quinolone resistance-determining regions of Aeromonas caviae isolated from diarrhoeal patients. Res Microbiol 2004;155(10):827-829.

34. Wattal C, Joshi S, Sharma A, Oberoi JK, Prasad KJ. Prescription auditing and antimicrobial resistance at a tertiary care hospital in New Delhi, India. J Hospital Infect 2005;59(2):156-158.

35. Arya SC, Agarwal N, Agarwal S. Comparison of two amoxicillin/clavulanic acid-resistant profiles employing two types of assay disks: A pilot study in 50 isolates from a tertiary care hospital in India. Curr Therap Res 2006;67(2):151-156.

36. Krishna BV, Patil AB, Chandrasekhar MR. Fluoroquinoloneresistant Vibrio cholerae isolated during a cholera outbreak in India. Transact Royal Soc Trop Med Hygiene 2006;100(3):224226.

37. Sharma NC, Mandal PK, Dhillon R, Jain M. Changing profile of Vibrio cholerae 01, 0139 in Delhi \& its periphery (2003-2005). Indian J Med Res 2007 May 1;125(5):633.

38. Arora S, Saha S, Bal M. Imipenem-resistance among multi-drug resistant clinical strains in urinary infections from Kolkata. Indian J Med Res 2007 May;125(5):689-692.

39. Jain A, Mondal R; Prevalence \&amp; antimicrobial resistance pattern of extended-spectrum beta-lactamase-producing Klebsiella spp isolated from cases of neonatal septicaemia, Indian J Med Res 2007;125(1):89-94.

40. Menezes GA, Harish BN, Sujatha S, Vinothini K, Parija SC; Emergence of vancomycin-intermediate Staphylococcus species in southern India, J Med Microbiol 2008 Jul; 57(Pt 7):911-912.

41. Chande CA, Shrikhande SN, Jain DL, Kapale S, Chaudhary H, Powar RM; Prevalence of methicillin-resistant Staphylococcus aureus nasopharyngeal carriage in children from the urban community at Nagpur. Indian J Public Health 2009; 53(3):196-198.

42. Manoharan A, Chatterjee S, Mathai D, SARI Study Group; Detection and characterization of Metallo beta lactamases producing Pseudomonas aeruginosa, Indian J Med Microbiol 2010;28(3):241-244.

43. Shenoy MS, Bhat GK, Kishore A, Hassan MK; Significance of MRSA strains in community associated skin and soft tissue infections, Indian J Med Microbiol 2010; 28(2):152-154.

44. Adhikari L. High-level aminoglycoside resistance and reduced susceptibility to vancomycin in nosocomial enterococci. J Global Infect Dis 2010 Sep;2(3):231.

45. Behera B, Mathur P. High levels of antimicrobial resistance at a tertiary trauma care centre of India. Indian J Med Res 2011 Mar;133(3):343.

46. Menezes GA, Harish BN, Khan MA, Goessens WH, Hays JP. Antimicrobial resistance trends in blood culture positive Salmonella Typhi isolates from Pondicherry, India, 2005-2009. Clin Microbiol Infect 2012;18(3):239-245.

47. Bagla J, Ghosh V, Ramji S, Gothi D. Antimicrobial susceptibility patterns following the change in antibiotic policy in NICU. Pediatr Infect Dis 2013;5(2):59-63.

48. Wattal C, Raveendran R, Goel N, Oberoi JK, Rao BK. Ecology of bloodstream infection and antibiotic resistance in the intensive care unit at a tertiary care hospital in North India. Braz $\mathrm{J}$ Infect Dis 2014;18(3):245-251.

49. Bouchiat C, El-Zeenni N, Chakrakodi B, Nagaraj S, Arakere G, Etienne J. Epidemiology of Staphylococcus aureus in Bangalore, India: the emergence of the ST217 clone and high rate of resistance to erythromycin and ciprofloxacin in the community. Microbes new infecti 2015;7:15-20. 
50. Agarwal R, Sankar J. Characterisation and antimicrobial resistance of sepsis pathogens in neonates born in tertiary care centres in Delhi, India: a cohort study. Lancet Global Health 2016;4(10):e752-760.

51. Gandra S, Mojica N, Klein EY, Ashok A, Nerurkar V, Kumari $\mathrm{M}$, et al. Trends in antibiotic resistance among major bacterial pathogens isolated from blood cultures tested at a large private laboratory network in India, 2008-2014. Int J Infect Dis 2016;50:75-82.

52. Gupta R, Malik A, Rizvi M, Ahmed M, Singh A. Epidemiology of multidrug-resistant Gram-negative pathogens isolated from ventilator-associated pneumonia in ICU patients. J Global Antimicrob Resis 2017;9:47-50.

53. Mohapatra DP, Debata NK, Singh SK. Extensively drug-resistant and pan drug-resistant Gram-negative bacteria in a tertiarycare hospital in Eastern India: A 4-year retrospective study. J Global Antimicrob Resis 2018 Dec;15:246-249.

54. Chaudhry D, Tomar P. Antimicrobial resistance: The next big pandemic. Int J Community Med Public Health 2017;4:26322636.

55. Swaminathan S, Prasad J, Dhariwal AC, Guleria R, Misra MC, Malhotra R, et al. Strengthening infection prevention and control and systematic surveillance of healthcare-associated infections in India. BMJ 2017;358:j3768.

56. Morgan DJ, Okeke IN, Laxminarayan R, Perencevich EN, Weisenberg S. Non-prescription antimicrobial use worldwide: A systematic review. Lancet Infect Dis 2011;11:692-701.

57. Bate R, Tren R, Mooney L, Hess K, Mitra B, Debroy B, Attaran A. Pilot study of essential drug quality in two major cities in India. PLoS One. 2009 Jun;4(6):e6003.

58. Lundborg CS, Tamhankar AJ. Antibiotic residues in the environment of South East Asia. BMJ 2017;358:j2440.

59. Forsberg KJ, Patel S, Gibson MK, Lauber CL, Knight R, Fierer $\mathrm{N}$, et al. Bacterial phylogeny structures soil resistors across habitats. Nature 2014;509(7502):612-616.

60. Chandy SJ, Naik GS, Balaji V, Jeyaseelan V, Thomas K, Lundborg CS. High-cost burden and health consequences of antibiotic resistance: the price to pay. J Infect Devel Countries 2014 Sep;8(09):1096-102.

61. Bhattacharya C, Das-Mondal M, Gupta D, Sarkar AK, Kar-Purkayastha S, Konar A. Infection in cirrhosis: A prospective study. Ann Hepatol 2019;18(6):862-868.

62. Strauss E. The impact of bacterial infections on the survival of patients with decompensated cirrhosis. Ann Hepatol 2014 Jan;13(1):7-19.

63. Fernández J, Bert F, Nicolas-Chanoine MH. The challenges of multi-drug-resistance in hepatology. Ann Hepatol 2016 Nov;65(5):1043-1054.

64. Nikaido H. Multidrug resistance in bacteria. Annu Rev Biochem 2009 Jul 7;78:119-146.

65. World Health Organization. Antimicrobial resistance: global report on surveillance. Geneva, Switzerland: WHO; 2014

66. Holcomb HG, Durbin KJ, Cho M, Choi KJ, Darling ND, Angerio AD. Methicillin-resistant Staphylococcus aureus as a threat to public health: a cellular approach. GU J Health Sci 2013;7:1-8.

67. Gebo KA, Burkey MD, Lucas GM, Moore RD, Wilson LE. Incidence of, risk factors for, clinical presentation, and 1-year outcomes of infective endocarditis in an urban HIV cohort. J Acquir Immune Defic Syndr 2006;43:426-432.

68. Yong D, Toleman MA, Giske CG, Cho HS, Sundman K, Lee $\mathrm{K}$, et al. Characterization of a new Metallo- $\beta$-lactamase gene, blaNDM-1, and a novel erythromycin esterase gene carried on a unique genetic structure in Klebsiella pneumoniae se- quence type 14 from India. Antimicrob Agents Chemother 2009;53(12):5046-5054.

69. Sinha M, Srinivasa H, Macaden R. Antibiotic resistance profile \& extended-spectrum beta-lactamase (ESBL) production in Acinetobacter species. Indian J Med Res 2007; 126: 63-67.

70. Gaur A, Garg A, Prakash P, Anupurba S, Mohapatra TM. Observations on carbapenem resistance by minimum inhibitory concentration in nosocomial isolates of Acinetobacter species: an experience at a tertiary care hospital in North India. J Health Popul Nutr 2008; 26:183-188.

71. Srivastava RK, Chaudhury RR, Bramhachari SK, Singh S, Guleria R, Sinha A, et al. National policy for containment of antimicrobial resistance India. Directorate General of Health Services, Ministry of Health and Family Welfare, Nirman Bhawan, New Delhi; 2011.

72. Özgenç O. Methodology in improving antibiotic implementation policies. J Hepatol 2016 Jun;6(2):143.

73. Cisneros JM, Pérez-Moreno MA, Gil-Navarro MV. Política de antibióticos. Comisión de infecciones y uso de antimicrobianos. Enfermedades Infecciosas y Microbiología Clínica. 2014 Oct 1;32(8):533-6.

74. World Health Organization. A step-by-step approach for development and implementation of hospital and antibiotic policy and standard treatment guidelines. WHO Regional Office for SouthEast Asia; 2011.

75. Simões AS, Gregório J, Póvoa P, Lapão LV. Practical guide for the implementation of Antibiotic Stewardship Programs. Lisboa: Instituto de Higiene e Medicina Tropical. 2015 Sep

76. Davey P, Brown E, Charani E, Fenelon L, Gould IM, Holmes A, Ramsay CR, Wiffen PJ, Wilcox M. Interventions to improve antibiotic prescribing practices for hospital inpatients. Cochrane Database of Systematic Reviews. 2013(4).

77. Malani AN, Richards PG, Kapila S, Otto MH, Czerwinski J, Singal B. Clinical and economic outcomes from a community hospital's antimicrobial stewardship program. Am J Infect Control 2013;41(2):145-148.

78. Pollack LA, Srinivasan A. Core elements of hospital antibiotic stewardship programs from the Centers for Disease Control and Prevention. Clin Infect Dis 2014;59(suppl 3):S97-100.

79. Dellit TH, Owens RC, McGowan JE, Gerding DN, Weinstein RA, Burke JP, et al. Infectious Diseases Society of America and the Society for Healthcare Epidemiology of America guidelines for developing an institutional program to enhance antimicrobial stewardship. Clin Infect Dis 2007 Jan 15;44(2):159-177.

80. Shlaes DM, Gerding DN, John Jr JF, Craig WA, Bornstein DL, Duncan RA, et al. Society for Healthcare Epidemiology of America and Infectious Diseases Society of America Joint Committee on the Prevention of Antimicrobial Resistance: guidelines for the prevention of antimicrobial resistance in hospitals. Clin Infect Dis 1997;25(3):584-99.

81. Masterton R, Drusano G, Paterson DL, Park G. Appropriate antimicrobial treatment in nosocomial infections - the clinical challenges. J Hospital Infect 2003;55:1-2.

82. Leekha S, Terrell CL, Edson RS. General principles of antimicrobial therapy. In Mayo Clinic Proceedings 2011 Feb 1 (Vol. 86, No. 2, pp. 156-167). Elsevier.

83. Masterton R. The importance and future of antimicrobial surveillance studies. Clin Infect Dis 2008;47(Supplement_1):S21-31.

84. Al-Tawfiq JA. The pattern and impact of infectious diseases consultation on antimicrobial prescription. J Global Infect Dis 2013 Apr;5(2):45. 